\title{
Dimension of Village Expenditure in Development Sector
}

\author{
Rita Martini ${ }^{1, *}$, Zulkifli Zulkifli $^{1}$, Sukmini Hartati $^{1}$, Endah Widyastuti $^{1}$ \\ ${ }^{1}$ Accounting Department, Polytechnic State of Sriwijaya, Palembang 30139, Indonesia \\ "Corresponding author. Email: ritamartini@ polsri.ac.id
}

\begin{abstract}
A study of village revenue and village expenditure in the development sector is needed to analyze the effect on villages in Lahat District. Secondary data are in the form of APBDes Realization Reports from the Community and Village Empowerment Service. Village revenue affects village expenditure in development. Village fund (DD) and village fund allocation (ADD) have a significant effect on the positive direction of village expenditure in the development sector. In Lahat Regency, the majority of villages use transfer funds to be allocated to village expenditure in the development sector. Because the small amount of village original revenue (PADes) is not possible to be allocated to village expenditure in the development sector, tax and retribution results section (BHPR) is due to overlapping of central and regional regulations.
\end{abstract}

Keywords: good government governance, village financial

\section{INTRODUCTION}

The poverty rate in Lahat District is still high compared to other districts in South Sumatra Province. This regency has the second highest number of poor people in South Sumatra at $16.81 \%$ in 2017 . In addition, in 2017 the number of poor people is still relatively high compared to the average number of poor people of South Sumatra at $13.19 \%$. The Head of Lahat Regency BPS stated that even though there has a decrease in percentage from 2017 , the poverty rate in Lahat is still relatively high [1].

When the budget expenditure is bigger in development expenditure, the poverty rate will decrease [2]. Funding for the implementation of village development programs and activities to improving the welfare of rural communities, improving the quality of human life and reducing poverty comes from the village expenditure in development sector [3]. The allocation of village expenditure in the development sector is expected to be able to reduce poverty so that the poverty rate will decline. Village development requires financing or adequate sources of village revenue. Village revenue consists of village original revenue (PADes), transfers, and other village revenue.

The dominant source of revenue and have a large proportion in all districts of the Province of South Sumatra compared to PADes are village funds (DD), village fund allocation (ADD) and tax and retribution results section (BHPR). The biggest recipient districts of DD realization include Lahat District, IDR 272 billion. Lahat District also received ADD and the $4^{\text {th }}$ and $3^{\text {rd }}$ largest BHPR in all districts in South Sumatra, each amounting to Rp 108 billion and IDR 4.2 billion. However, the number of Lahat District PADes is only IDR 640 million or the lowest is 7 (seven) of all Regencies in South Sumatra Province [4].
All of the village's large sources of revenue, especially in the form of transfers from the central and district/city governments, should be focused on by the village government to develop infrastructure and empower communities in line with the increasing welfare of rural communities. The findings of the relatively high number of poor people in Lahat District who did not experience a significant decline indicate that the sources of income allocated to village spending in the development sector in Lahat District villages have not been able to reduce poverty.

The large number of village revenue sources, especially DD and ADD, should be able to be focused by the government for infrastructure development and community empowerment in order to improve the welfare of communities in rural areas and reduce poverty in the villages. Village governments are given the authority to increase their own PADes without interference from the central government or regional governments [5] and [6]. To support good village revenue governance, one of them is influenced by the effectiveness of internal control [7] and [8].

This study aims to analyze the influence of PADes, DD, ADD and BHPR partially or simultaneously on village expenditure in development sector in the village government of Lahat District. Exposure to this paper begins with an introduction, followed by a study of theory and the development of hypotheses, research methods, and the results of research and discussion. At the end, it contains conclusions and suggestions for related parties. 


\section{LITERATURE REVIEW AND HYPOTHESIS DEVELOPMENT}

\subsection{Stewardship in Public Sector}

The grand theory used in this research is that Stewardship theory, views management (village government) as a party that can be trusted to act as well as possible for the public interest or stakeholders, for the interests of the principal (community and government). Stewardship theory describes a situation or condition in which management is not motivated by individual goals but rather prioritizes the interests of the organization [9]. The theory assumes that there is a strong relationship between organizational satisfaction and success. Organizational success describes maximization utility of principals and management groups. The utility maximization of this group will ultimately maximize the interests of individuals within the group of organizations.

\subsection{PADes on Village Expenditure in Development Sector}

PADes is the village original revenue from village authority based on the origin and authority of the village local scale. PADes is revenue generated by village businesses, village wealth, self-help and participation, the results of mutual cooperation and other legitimate PADes. When PADes is bigger may the village to fulfill the expenditure needs of its own village without waiting for assistance from the central government [2]. PADes has a significant effect on village expenditure in development [10], [11], [12], [13], and [14]. The above description underlies the hypothesis:

$\mathrm{H}_{1}$ : PADes has a significant effect in development expenditure.

\section{RESEARCH METHODOLOGY}

This research is associative causal with quantitative methods. The researcher analyzed the causal relationship between the variables PADes, DD, ADD and BHPR and village expenditure in the development sector. PADes, DD, ADD and BHPR are influencing variables, while village expenditure in development is an affected variable.

The study population of all villages in Lahat Regency consisted of 360 villages. Samples were taken by purposive sampling with criteria: 1) Villages that collected Budget APBDes for Budget year 2018 in Lahat Regency DPMD 2) APBDes LRA consist DD, ADD and BHPR components but does not have PADes. Based on these criteria, a sample of 232 villages was obtained.

Data collection using the library method, such as reading and studying the literature relating to the problem under study. This secondary data consists of the LAB APBDes of 2018 obtained directly from the Lahat Regency DPMD.
The results of normality test, the points spread around the diagonal line, and the spread follows the direction of the diagonal line. So the regression model meets the assumptions of normality, meaning that the data in this study come from populations that are normally distributed. The results of multicollinearity test showed that the tolerance values of the four variables were more than 0.10 and the Variance Inflation Factor (VIF) value was less than 10. The regression model did not experience multicollinearity problems. Heteroscedasticity test produces a significance value of four independent variables more than 0.05. It was concluded that there was no heteroscedasticity problem in this study. Based on the decision-making criteria, it means that there is no auto correlation.

The research model uses multiple linear regression which refers to Priyatno [15], namely:

$\mathrm{BDBP}=\mathrm{a}+\beta \mathrm{PADes}+\beta \mathrm{DD}+\beta \mathrm{ADD}+\beta \mathrm{BHPR}+\mathrm{e}$ Information:

$\mathrm{Y}=$ Village Expenditures for Development (BDBP)

$\mathrm{X} 1=$ Village Original Income (PADes)

$\mathrm{X} 2=$ Village Fund (DD)

$\mathrm{X} 3$ = Village Fund Allocation (ADD)

X4 = Tax and Retribution Results Section (BHPR)

$\mathrm{a}=$ Regression constant

$\beta=$ Regression coefficient

e $=$ Error

\section{RESULTS AND DISCUSSION}

\subsection{Result}

Based on the results of multiple linear regression analysis the regression equation is obtained:

$\mathrm{BDBP}=-951328828.93+0.272$ PADes $+0.578 \mathrm{DD}+$ 0.834 ADD - 2.419 BHPR + e

BHPR has a negative direction towards village expenditure in the development sector. Whereas PADes, DD and ADD have a positive direction toward village expenditure in development.

The results of the F statistical test show $\mathrm{F}$ count $>\mathrm{F}$ table $(12.826>2.411)$ and significance values $(0,000<0.05)$ then $\mathrm{H}_{1}$ is accepted. PADes, DD, ADD and BHPR simultaneously influence village expenditure in development sector. Based on the results of the statistical test $\mathrm{t}$ can be interpreted: 1) PADes does not have a significant effect on village expenditure in the development sector; 2) DD has a significant effect on village expenditure in the development sector; 3) ADD has a significant effect on village expenditure in the development sector; and 4) BHPR has no significant effect on village expenditure in the development sector.

The test results of the determination coefficient show the effect of PADes, DD, ADD and BHPR on village expenditure in the field of development by $45.2 \%$. The 
remaining $54.8 \%$ are influenced by other variables not examined in this research model.

\subsection{Result}

There is no significant influence between PADes on village expenditure in the development sector, this result is in line with Purbasari et al. [11]. This condition is caused by not allowing the village government to allocate PADes to village development spending. Villages in Lahat District tend to have small and similar PADes. The majority of villages still depend on transfer funds from the central and regency/city governments in the form of $\mathrm{DD}, \mathrm{ADD}$ and BHPR as the main revenue sources. The lower PADes obtained by village, the village cannot fulfill all of its village expenditure which consequently will depend on the central government [2] and [16].

In line with Purbasari et al. [11], Dewi and Irawan [13] and Puspawati et al. [14], there is a significant influence between DD on village expenditure in the development sector. DD affects the allocation of village expenditure in the development sector, because based on Village Minister Regulation (Permendesa PDTT) number 21 of 2015 concerning DD Priority for use in 2016 the priority of DD use is directed to finance the implementation of villagescale programs and local activities in the field of village development and empowerment of rural communities [11]. This study did not supported by Puspawati et al. [14] which proves DD does not affect village expenditure in the development sector. This condition is due to the allocation of DD by the central government for 2017 (PMK 49 of 2016 concerning Procedures for Allocation, Distribution, Use, Monitoring and Evaluation of DD) still using the formula for the amount of village funds originating from basic allocations plus formula allocation where the basic allocation of DD (equal to $90 \%$ ) equal to each village.

Law number 4 of 2018 concerning the Determination of Magnitude and Allocation of ADD Financial Assistance stipulates 2 (two) types of ADD use. One of the uses of $\mathrm{ADD}$, which is basic allocation, is given to each village evenly within the district. The basic allocation is used to fund the holding of village authority consisting of organizing village administration, implementing village development, community development, fostering village communities and unexpected shopping. In line with [10], [12], [13], and [14], there is a significant influence between ADD on village expenditure in development sector.

This study is not supported by Purbasari et al. [11] and Dewi \& Irama [14]. The allotment of ADD is mostly to finance the permanent income of village heads and village officials as well as village operations. This means that ADD is prioritized, not used for village expenditure in the field of development. This condition indicates that the amount of ADD does not significantly influence the allocation of village expenditure in the development sector [14].

There is no significant influence between BHPR and village expenditure in the development sector, in line with Purbasari et al. [11] and Puspawati et al. [14]. Law number
28 of 2009 requires that the regency/city government allocate the results of district tax revenues of at least $10 \%$ to villages in their area, taking into account the aspects of equity and village potential and the use of which is fully determined by the recipient village. Regarding retribution revenue sharing, a portion of the proceeds from the receipt of certain retribution is set for the village by paying attention to aspects of village involvement in the provision of services such as replacement fees for identity cards (KTP) and civil registration certificates (ACS). However, the Lahat Regent Regulator number 2 of 2018 concerning the allocation of BHPR to villages in the Fiscal year 2018 is not prioritized for village development activities but for the field of village administration, community empowerment and community development.

The result of this study was supported by Sulistyoningtyas [10], Dewi and Irama [12] which prove that PADes and ADD affect village spending. The same results were also stated Purbasari et al. [11] and Irawan et al. [13] PADes, DD and ADD simultaneously influence village expenditure in the development. When the PADes, DD, ADD and BHPR, the village expenditure are bigger, so that the development sector will increase. When village revenue, village expenditure are higher, that can be used for village development [17]. The implementation of village development will require financing or adequate sources of village revenue.

\section{CONCLUSION}

The implementation of village development requires financing or adequate sources of village revenue. Village revenue affects the amount of village expenditure that can be used for village development. When PADes, DD, ADD and BHPR are higher, the village expenditure in the development sector will increase.

Partially only DD and ADD have a significant effect on village expenditure in development. This condition indicates that village expenditure in the development sector is derived from allocations originating from $\mathrm{DD}$ and ADD. Simultaneously PADES, DD, ADD, and BHPR have a significant effect on rural village expenditure in development sector with a determination coefficient of $45.20 \%$.

The opportunity to develop more specific dependent and independent variables in order to be able to provide almost all the information needed to predict variations in the dependent variable. It is also recommended to increase the time period and object of research in order to improve the accuracy of the quality of the research results.

\section{ACKNOWLEDGMENT}

This research was supported by State Polytechnic of Sriwijaya, Indonesia. The authors thank our colleagues who provided insight and expertise that greatly assisted the research. 


\section{REFERENCES}

[1] E. Amin, "BPS Lahat: Jumlah Penduduk Miskin di Lahat Tertinggi ke-2 di Sumatera Selatan," Palembang, 2018. Retrieved from Sripoku.com: http://palembang.tribunnews.com/2018/11/07/bpslahat-jumlah-penduduk-miskin-di-lahat-tertinggike-2-di-sumatera-selatan.

[2] N. I. Susilowati, D. Susilowati and S. Hadi, "Pengaruh Alokasi Dana Desa, Dana Desa, Belanja Modal, dan Produk Domestik Regional Bruto terhadap Kemiskinan Kabupaten/Kota di Jawa Timur," Jurnal Ilmu Ekonomi, vol. 2, no. 1, pp. 189-202, 2017.

[3] I. Bastian, Akuntansi untuk Kecamatan dan Desa, Jakarta: Erlangga, 2015.

[4] Kemendesa PDTT, "Anggaran Pendapatan dan Belanja Desa Tahun 2017," Village Ministry of The Republic of Indonesia, Jakarta, 2018. Retrieved from www.spede.ppmd.kemendesa.go.id.

[5] A. A. Jiwangga and A. Prastyawan, "Partisipasi Masyarakat dalam Upaya Peningkatan Pendapatan Asli Desa di Desa Kedungpring Kecamatan Balongpanggang Kabupaten Gresik," Jurnal Mahasiswa Unesa, vol. 3, no. 1, pp. 1-8, 2016.

[6] R. Martini, A. Resy and Z. Zaliah, "Pendapatan Asli Daerah Provinsi Sumatera Selatan: dari kontribusi retribusi pasar," Jurnal Kajian Ekonomi \& Keuangan Daerah, vol. 5, no. 1, pp. 58-71, 2019. doi: 10.24114/jpkm.v25i2.13916.

[7] R. Martini, K. R. Sari and R. S. Wardhani, "Analisis Penerapan Good University Governance Melalui Efektivitas Pengendalian Intern dan Komitmen Organisasional," Simposium Nasional Akuntansi 18, 2015.

[8] R. Martini, S. Hartati, Z. Zulkifli and E. Widyastuti, "Sistem Pengendalian Intern Pemerintah atas Akuntabilitas Pengelolaan Keuangan Dana Desa di Kecamatan Sembawa," Jurnal Akademi Akuntansi, vol. 2, no. 1, 2019. doi: 10.22219/jaa.v2i1.8364.

[9] J. H. Davis, F. D. Schoorman and L. Donaldson, "Toward a Steawardship Theory of Management,"
Academy of Management Review, vol. 5, no. 1, pp. 20-47, 1991.

[10] L. Sulistiyoningtyas, "Pengaruh Alokasi Dana Desa dan Pendapatan Asli Desa terhadap Belanja Desa di Kecamatan Baron," Simki-Economic, vol. 1, no. 3, pp. 11-14, 2017.

[11] H. Purbasari, B. W. Wardana and I. A. Pangestu, "Analisis Pengaruh Pendapatan Asli Desa, Dana Desa, Alokasi Dana Desa dan Bagi Hasil Pajak dan Retribusi terhadap Belanja Desa Bidang Pekerjaan Umum dan Pertanian (Studi Empiris di Seluruh Desa se-Kabupaten Sukoharjo," in The 7th University Research Collaquium (URECOL) 2018 STIKES PKU Muhammaddyah Surakarta, Surakarta, 2018.

[12] R. S. Dewi and O. N. Irama, "Pengaruh Pendapatan Desa, dan Alokasi Dana Desa terhadap Belanja Desa dan Kemiskinan," Jurnal Riset Akuntansi Multiparadigma (JRAM), vol. 5, no. 2, pp. 11-18, November 2018.

[13] M. A. Irawan, S. Rahayu and W. Aminah "Pengaruh Pendapatan Asli Desa, Dana Desa, dan Alokasi Dana Perimbangan Desa terhadap Belanja Desa (Studi Kasus pada Desa di Kabupaten Bandung Tahun 2017)," Jurnal Aksara Publik, vol. 2, no. 4, pp. 190-202, Desember 2018.

[14] D. Puspawati, H. Purbasari, S. Lestari and K. Pratiwi, "Analisis Pendapatan Asli Desa, Dana Desa, Alokasi Dana Desa, dan Bagi Hasil Pajak dan Retribusi terhadap Belanja Modal Desa Di Kabupaten Wonogiri Tahun 2017," in The 8th University Research Colloquium 2018 Universitas Muhammadiyah Purwokerto, Puwokerto, 2018.

[15] D. Priyatno, Cara Kilat Belajar Analisis Data dengan SPSS 20, vol. 1, Yogyakarta: Andi, 2012.

[16] R. Martini, K. R. Sari, T. Somadi and I. W. Karman, "Financial Independence of The South Sumatra Regional Government," Advanced in Social Science, Education and Humanitiies Research, vol. 354, pp. 360-364, 2019.

[17] J. Hoesada, “Akuntansi Revaluasi Aset Pemerintah," Komite Standar Akuntansi Pemerintah (KSAP), Jakarta, 2016. https://www.ksap.org/sap/2016/ 